DOI 10.7764/rcia.v45i3.1783

\title{
Peri-urban family farming and agricultural earnings: The effect of long-term participation in an extension program in a metropolitan area
}

\author{
Sofia Boza ${ }^{1}$ and Roberto Jara-Rojas ${ }^{2}$ \\ 'Universidad de Chile, Department of Agricultural Economics. Santa Rosa Av. 11315, La Pintana, Santiago, Chile. \\ ${ }^{2}$ Universidad de Talca, Department of Agricultural Economics. 1 Poniente 1141, Talca, Chile.
}

\begin{abstract}
S. Boza and R. Jara-Rojas. 2018. Peri-urban family farming and agricultural earnings: The effect of long-term participation in an extension program in a metropolitan area. Cien. Inv. Agr. 45(3): 200-209. The objective of this paper is to assess the effect of long-term participation in an extension program on peri-urban family farming earnings. For this purpose, a survey of a sample of 156 participants in the Local Development Program (PRODESAL) of the Chilean National Institute for Agricultural Development (INDAP) was conducted in the Metropolitan Region of Santiago. Half of the respondents were long-term participants with at least four yrs in the program, and the rest of the farmers were one-yr beneficiaries. A treatment regression model (TRM) with a binary endogenous variable was used to identify differences among long- and short-term farmer participation in PRODESAL. The first stage of the model is a probit regression that identifies factors influencing long-term participation in PRODESAL. The second stage has the total value of production (TVP) as a dependent variable, which captures agricultural earnings, and one of the explanatory variables is the binary endogenous regressor of the first stage of the model. The results show a positive impact of long-term participation in PRODESAL on TVP. Other variables, such as farm size, fertilization and access to credit, were significant and positively related to TVP as well. Education and social capital are shown to be variables that increase the probability of long-term participation of family farmers in the program.
\end{abstract}

Keywords: Chile, integral extension program, long-term participation, Metropolitan Region, peri-urban agriculture.

\section{Introduction}

Most of the farms around the world, especially in developing countries, are family farms (Van Vliet et al., 2015). However, their opportunities for success and access to resources vary sig-

Received Apr 19, 2017. Accepted Nov 13, 2018.

Corresponding author: rjara@utalca.cl nificantly between regions. In South America, there is extreme inequality in the distribution of land: $82 \%$ of all farms are family farms, but they hold only $18 \%$ of the agricultural land (Graeub et al., 2016). The inequality of land ownership contributes to rural-urban migration because of the low potential for production and income generation (Lapola et al., 2014). In Latin America, $80 \%$ of the population lives in urban 
areas, which is the highest rate worldwide (IDB, 2015). Urban sprawl has led to land shortages for farming ( $\mathrm{Li}, 2018)$, increasing the risk of food insecurity (Zeeuw and Dubbeling, 2009). The promotion of peri-urban agriculture is essential for providing healthy food to urban centers (FAO, 2014). When peri-urban farms are family farms, they encourage access to healthy food for the most vulnerable groups (Jacoby et al., 2014). Other critical factors for family farming that limit its competitiveness are capital and credit constraints, limited access to infrastructure, and low rates of technology adoption, market integration and organization (Medina et al., 2015). Therefore, family farming in Latin America is both vulnerable and relevant to the local food supply. Although there is a wide variety of approaches, most countries in the region have policies in place to support family farming, with agricultural extension programs as one of the main instruments applied (Sabourin et al, 2014). These programs aim to promote technological adoption and improve farmers' skills and often include additional benefits such as nutritional or health services (Dethier and Effenberg, 2012).

In Chile, family farming is mainly supported by the National Institute for Agricultural Development (INDAP), founded to promote its economic, social and technological development. INDAP has experienced significant changes in its procedures and alignments since its establishment in the 1960s. In the late 1970s, INDAP outsourced the provision of extension services for family farmers to private agents. This was a top-down approach with standardized technical solutions (Namdar-Irani and Sotomayor, 2011). Notable adjustments took place in 1990 since the objective of INDAP's extension programs moved from "increasing yields" to "diversifying and increasing yields". The methodologies evolved to be more horizontal. Additionally, farmer organizations and municipal governments became important actors in the extension system, while private for-profit consultant firms maintained their participation (Berdegué and Marchant, 2002).
Among the innovations in INDAP's strategy in the 1990s was the creation of the Local Development Program (PRODESAL). PRODESAL aims to build technical and productive capacity among low-income, subsistence and family farmers and their families, with the goal of increasing their participation in revenues along the value chain (Jara-Rojas et al., 2018). PRODESAL is implemented at the local level through agreements between INDAP and municipal governments (Challies and Murray, 2011). PRODESAL is the most important extension program in terms of coverage and number of beneficiaries in Chile today (Aguirre, 2012). One of its main characteristics is its comprehensive approach. In addition to supporting farmers on technical issues, the program focuses on socio-economic concerns, such as the health and human capital of the family farm (Namdar-Irani and Sotomayor, 2011). PRODESAL does not have defined egress criteria for its beneficiaries, which enables them to participate for long periods, up to a maximum of four yrs (PUC, 2010, INDAP, 2017). Once that period has expired, the producer can re-apply because having received benefits previously does not weigh into the selection process ${ }^{1}$.

PRODESAL farmers are organized into Communal Operating Units (COUs), which are groups of variable sizes linked by their interests, productive vocation, identity, geographic proximity, social and productive interrelations, among others. COUs also serve as spaces for participation, coordination and dialogue among farmers, with the goal of expanding the social and economic capital of their territories. The municipal governments or other executing agencies are responsible for selecting the beneficiaries in collaboration with the respective INDAP area agency. There is no standardized protocol for this process beyond compliance with the official selection criteria (Ramírez et al., 2014); however,

\footnotetext{
${ }^{1}$ The criteria are limits in the value of the assets, in the number of hectares, that the main activity of the beneficiary is agriculture, not having debt with INDAP and not participating in other public promotion programs that are considered to have very similar purposes. (see Jara-Rojas et al., 2012 for classification details).
} 
the ability of farmers to participate and organize a new COU depends on social capital, motivation and access to information.

The coverage of PRODESAL has increased significantly, from 54,108 farmers in 2010 to 68,188 in 2017 (INDAP, 2018), with a potential of approximately 175,000 . There are no precise official figures on the fluctuation rate among long-term participants and new farmers enrolled in the program; however, an analysis conducted by Ramírez et al. (2014) for 2008-2012 shows that of the 104,914 total beneficiaries, $45.5 \%$ remained during the complete period. The average annual entry of new farmers who were not beneficiaries in the previous yr was approximately 14,000.

The aim of this article is to assess the effects of peri-urban family farmers' long-term participation in an integrated, not only technically oriented extension program, using the case of PRODESAL in the Metropolitan Region of Santiago (MRS). This assessment is conducted assuming that the aim of PRODESAL is to build technical and productive capacities among family farmers with the goal of increasing their share of the revenues along the value chain and thus increasing agricultural earnings. This research contributes to the increasing literature on agricultural extension, assessing the impact of a program with an integral approach and frequent long-term participation, features that are common in similar initiatives in other countries. Additionally, it contributes to the existing research on the characteristics of peri-urban agriculture.

\section{Materials and methods}

\section{Study area and data}

The area under study encompasses the Metropolitan Region of Santiago in Central Chile (Figure 1). According to the MRS government, $40.5 \%$ of the Chilean population lives in this area, despite its relatively small size. Additionally, $45.6 \%$ of the nation's gross domestic product is generated in the MRS (Banco Central, 2016). The MRS has been experiencing population overgrowth, influenced by the high level of centralization in Chile. The MRS is divided into 52 districts. In the center of the MRS, 34 districts form the main urban area in Chile, known as "Gran Santiago". Encircling those districts, there is a belt of 18 peri-urban districts with lower population density. However, those districts have experienced significant real estate development in the last decade (Cáceres, 2015).

Despite the high rate of urbanization and the $75 \%$ reduction in the number of farms between 1976 and 2007 (INE, 2007), the MRS still accounts for $26.5 \%$ of the total area for horticulture in Chile, $17.3 \%$ for fruits and $9.4 \%$ for vineyards (ODEPA, 2018). Most farms in the MRS are family farms. An investigation based on data from the last agricultural census estimated that $87.9 \%$ of the regional farms are potential INDAP beneficiaries (Aedo and Alvear, 2010). There were 5,096 farmers served by INDAP in 2017 in the MRS, of which 3,695 belonged to PRODESAL (INDAP, 2018).

The data analyzed in this article were obtained from a survey administered to 156 family farmers located in six peri-urban districts in the southern MRS between January and April 2013. The sample includes 78 beneficiaries of PRODESAL from 2009 to 2012 and 78 that were enrolled in 2012. The questionnaire was divided into three main sections: i) personal characteristics of the farmers: age, gender, level of education, employment status, type of land tenure and participation in associations; ii) technical and production features: land size, use of fertilization and irrigation, and access to credit to finance investments; and iii) farm income and farming system.

\section{Methodological approach and empirical model}

To capture the long-term effect of farmers' participation in the PRODESAL on agricultural earnings, we estimate a treatment regression model (TRM) 


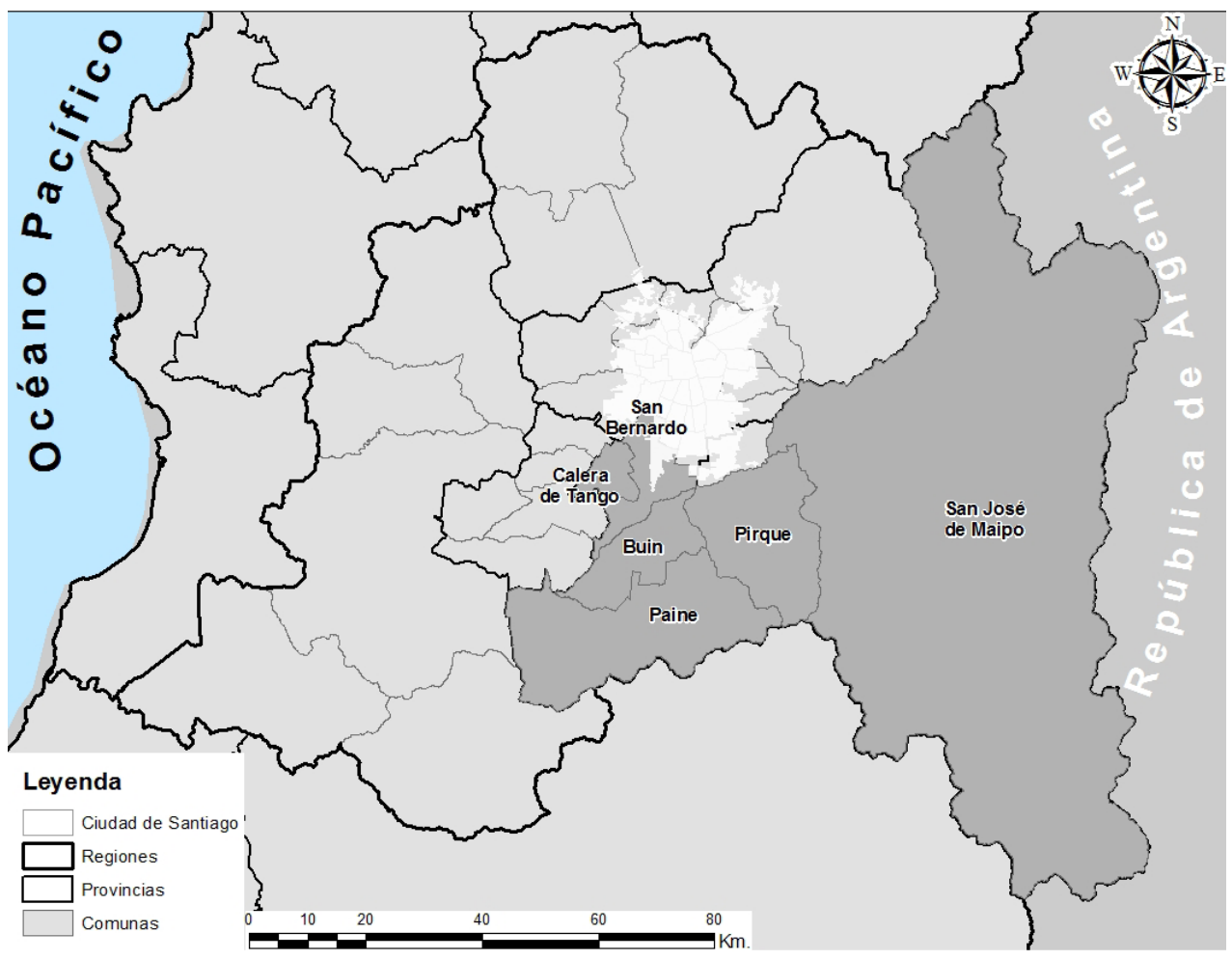

Figure 1. The Metropolitan Region of Chile

with a binary endogenous variable (Cameron and Trivedi, 2010) using the total value of production (TVP) as a dependent variable. The methodological approach includes two equations in which the first stage is a probit model that denotes farmers' long-term participation in PRODESAL. Let $y_{1}$ (TVP) depend in part on $y_{2}$ (PRODESAL), a binary endogenous regressor. We introduce an unobserved latent variable, $y_{2}^{*}$, that determines whether $y_{2}=1$, which reflects long-term participation in the program, or $y 2=0$, which implies short-term participation in the program. Thus, the model can be written as:

$y_{1 i}=\beta_{1} y_{2 i}+x_{1 i}^{\prime} \beta_{2}+\mu_{i}$

$y_{2 i}^{*}=\grave{x}_{1 i} \pi_{1 j}+\grave{x}_{2 i} \pi_{2 j}+\nu_{i}$

$y_{2 i}= \begin{cases}1 & \text { if } y_{2 i}^{*}>0 \\ 0 & \text { otherwise }\end{cases}$

The errors $\left(\mu_{\mathrm{i}}, v_{\mathrm{i}}\right)$ are assumed to be correlated bivariate normal with $\operatorname{Var}\left(\mu_{\mathrm{i}}\right)=\sigma^{2}, \operatorname{Var}\left(v_{\mathrm{i}}\right)=1$, and $\operatorname{Cov}\left(\mu_{\mathrm{i}}, v_{\mathrm{i}}\right)=\rho \sigma^{2}$. The binary endogenous regressor $y_{2}$ can be perceived as a treatment in- dicator; if $y_{2}=1$, the farmer received long-term treatment, and if $y_{2}=0$, the farmer received shortterm treatment. Handschuch et al. (2013) use a similar model to identify the factors influencing Good Agricultural Practices certification and its impact on farm management and income among export-oriented raspberry farmers in Chile. Our empirical model suggests that farmers' long-term participation in PRODESAL has a positive effect on agricultural earnings, captured as total value of production (TVP). As we stated earlier, the decision to participate in a Communal Operating Unit, which is the initial step to be a beneficiary of PRODESAL, is not directly observed. The probit model captures the variables that influence voluntary long-term participation in PRODESAL, which are related to human and social capital variables such as the age of the farmer, education, number of family members, land tenure, off-farm work and participation in a farmers' association. TVP is also determined by farm size, use of inputs (fertilizers), farming system and access to credit. Thus, our empirical model can be written as: 
TVP ${ }_{i}=\alpha_{i}+\beta_{1}$ PRODESAL $_{i}+\beta_{2}$ SIZE $_{i}+\beta_{3}$ FERT $_{i}+\beta_{4}$ ACTYPE $+\beta_{5}$ CREDIT $_{i}+\mu_{i}$
PRODESAL $_{i}=\gamma_{i}+\pi_{1} A G E_{i}+\pi_{2}$ GENDER $_{i}+\pi_{3}$ EDUC $_{i}+\pi_{4}$ FAM $_{i}+\pi_{5}$ TENURE $_{i}+\pi_{6}$ OFFARM $_{i}+\pi_{7}$ ASOC $_{i}+v_{i}$

where TVP is a dependent variable measured in Chilean pesos (\$), and PRODESAL is the binary endogenous treatment variable. In our case, if PRODESAL is equal to 1 , the farmer belonged to the program between 2009 and 2012, and if PRODESAL $=0$, the farmer was a short-term participant and was part of the program for the yr 2012. The definitions of the independent and instrumental variables are presented in Table 1, as well as their descriptive statistics.

\section{Results and discussion}

Of the farmers surveyed, $56.8 \%$ are male, and $43.2 \%$ are female. The average age of the sample is $54.9 \mathrm{yrs}$. Of the respondents, $45.1 \%$ have not completed any level of formal education, $12.9 \%$ have incomplete primary education, $18.7 \%$ have completed secondary education, and $23.3 \%$ have higher education. The average number of household members is 3.69; of them, 1.3 work on the farm. The most common agricultural products are vegetables, flowers, poultry and beekeeping. The average farm size is 0.51 hectares. A total of $38.1 \%$ of the farmers use chemical fertilizers. We found low participation in associations when assessing social capital: $88.4 \%$ of the farmers do not participate in associations. The average monthly TVP is 319,148 CLP, with a standard deviation of 483,077 CLP, showing relatively high heterogeneity. Additionally, $31.6 \%$ of the respondents have an off-farm job, and $10.3 \%$ of the sample has accessed credit to finance their agricultural activities within the last five yrs. The socio-economic characteristics of the sample are

Table 1. Description and definition of the variables used in the econometric model

\begin{tabular}{|c|c|c|c|c|}
\hline \multirow[t]{2}{*}{ Variables } & \multirow[t]{2}{*}{ Definition } & \multicolumn{2}{|c|}{ Continuous variables } & \multirow{2}{*}{$\begin{array}{l}\text { Dummy variables } \\
(\%=1)\end{array}$} \\
\hline & & Mean & S.D. & \\
\hline $\begin{array}{l}\text { Dependent } \\
\text { Variable, TVP }\end{array}$ & $\begin{array}{l}\text { Total Value of Production of the household in Chilean } \\
\text { pesos }(\$) \text { per month }\end{array}$ & 319,148 & 483,077 & \\
\hline \multicolumn{5}{|l|}{ Treatment } \\
\hline Variable & 1 if the farmer belongs to PRODESAL program, since & & & 49.7 \\
\hline PRODESAL & 2009 year, 0 if farmer is an earlier participant (2012) & & & \\
\hline \multicolumn{5}{|c|}{ Independent variables } \\
\hline LAND & Farm size in hectares & 0.51 & 0.99 & \\
\hline FERT & 1 if the farmer uses fertilizer, 0 otherwise & & & 38.1 \\
\hline ACTYPE & $\begin{array}{l}1 \text { if the main activity are crops, } 0 \text { the main activity is } \\
\text { animal production }\end{array}$ & & & 60.1 \\
\hline CREDIT & 1 if the farmer received credit, 0 otherwise & & & 10.3 \\
\hline \multicolumn{5}{|c|}{ Instrumental variables } \\
\hline AGE & Age of head of household in years & 54.9 & 13.7 & \\
\hline GENDER & 1 if the farmer is male, 0 otherwise & & & 56.8 \\
\hline EDUC1 & $\begin{array}{l}1 \text { if the farmer has incomplete elementary school, } 0 \\
\text { otherwise (the omitted category) }\end{array}$ & & & 45.1 \\
\hline EDUC2 & $\begin{array}{l}1 \text { if the farmer has incomplete secondary school, } 0 \\
\text { otherwise }\end{array}$ & & & 12.9 \\
\hline EDUC3 & $\begin{array}{l}1 \text { if the farmer has complete secondary school, } 0 \\
\text { otherwise }\end{array}$ & & & 18.7 \\
\hline EDUC4 & 1 if the farmer has high education, 0 otherwise & & & 23.3 \\
\hline FAM & Number of family members working on-farm & 1.3 & 1.1 & \\
\hline TENURE & 1 if the farmer has own land, 0 otherwise & & & 52.9 \\
\hline OFF-FARM & 1 if the farmer has extra-job besides farm, 0 otherwise & & & 31.6 \\
\hline ASOC & $\begin{array}{l}1 \text { if the farmer participates in farmer's association, } 0 \\
\text { otherwise }\end{array}$ & & & 11.6 \\
\hline
\end{tabular}


in line with previous research regarding family farming in Chile (Donoso et al., 2010; Jara-Rojas et al., 2012; Berdegué and Rojas, 2014; Boza et al., 2016a) and specifically in the MRS (Boza et al., 2018; 2016b). There are some unique aspects, including reduced average farm size and a high percentage of respondents who have not completed any formal education.

The econometric results are presented in Table 2. The model results are divided into two sections. The first stage probit model denotes farmers' long-term participation in PRODESAL, where five of nine estimated parameters are statistically significant at least at the $10 \%$ level. The second part of the econometric model is the total value of production of the household (TVP), in which four of the five estimated parameters are statistically significant at least at the $10 \%$ level. Additionally, the rho $(\rho)$ parameter is significant at the $1 \%$ level and confirms that long-term participation in PRODESAL is endogenous and that using a two-stage model is therefore suitable in this case.

Regarding the results for the probit model, the variables $A G E(\mathrm{p}<0.1), E D U C 2(\mathrm{p}<0.1), E D U C 4$ $(\mathrm{p}<0.05)$ and $A S O C(\mathrm{p}<0.1)$ have a positive association with long-term participation in PRODESAL, while OFF-FARM $(\mathrm{p}<0.01)$ has a negative impact. Long-term participants, compared with short-term participants, can be characterized as being older or more experienced farmers, having a higher level of education, belonging to farmers' associations, and having a lower incidence of off-farm employment. These results are consistent with those of Donoso et al. (2010), who evaluated the impact of INDAP's credit program. The authors found significant differences between participant and non-participant farmers that were related to age and generation of off-farm income, among other things.

Regarding the TVP function, the variable SIZE is positive and significantly related to monthly farm income $(\mathrm{p}<0.01)$, which means that producers with a greater number of hectares generate higher revenues. This relationship was predictable because one way to grow production is to expand farm size. Technical changes improve production systems and help to raise TVP by increasing yields. In this sense, the variable FERT is also positive and significant $(\mathrm{p}<0.01)$, meaning that the use of fertilizer has

Table 2. Two equation instrumental variable model results

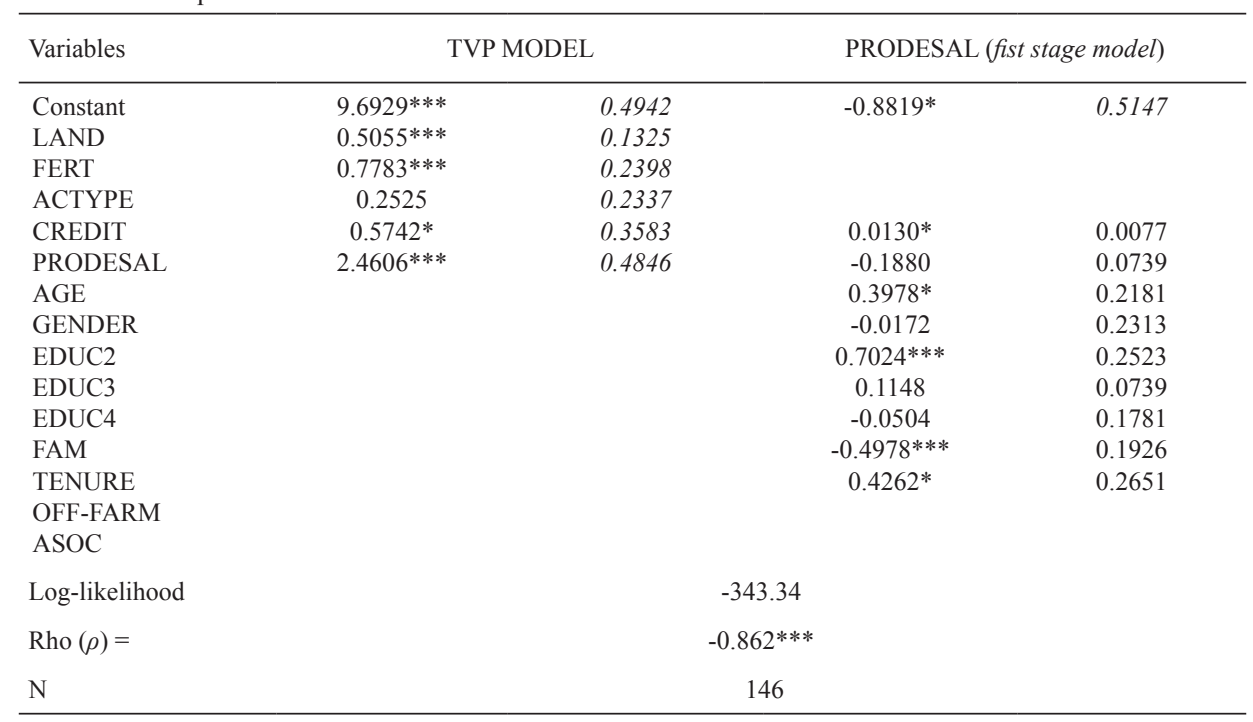

* Significant at 10\%; ** Significant at 5\%; *** Significant at $1 \%$. 
a supportive effect on farm income. This is, $a$ priori, another expected result considering that facilitating access to fertilizers, for example, through input subsidies, has typically been a strategy for agricultural growth in developing countries (Brooks, 2010). However, the generalized effectiveness of this type of policy has been doubted from technical (Duflo et al., 2008; Sheahan et al., 2013) and economic perspectives (Jonasson et al., 2014).

The parameter of the variable CREDIT also has a positive and significant effect on farm income $(p<0.1)$. These results are consistent with those of previous studies, such as those by Khandker and Koolwal (2016), Girabi and Godfrey (2013), Saleem and Jan (2011), and Mavimbela et al. (2010), who found access to credit to have a positive impact on the productivity of small-scale family farmers and on the revenues generated through their activities. However, in Chile, von CramonTaubadel and Saldías (2014) showed a dissimilar impact of access to credit on efficiency due to the type of production, which in turn, according to Reyes and Lensink (2011), is significantly related to farmers' social capital.

Similarly, the variable PRODESAL is positive and significantly related to farm income $(\mathrm{p}<0.01)$. This shows an impact of PRODESAL on the economic revenues of its long-term beneficiaries. Finally, the main farm activity (ACTYPE) is not significant for income generation. This suggests that the effects of the program are transversal to small-scale crop and animal production systems.

In conclusion, the results obtained show that the farms of long-term participants generate a significantly higher level of income, which implies a positive effect of the program on its impact variable. First-stage regression outcomes also show that long-term participants had some unique characteristics in comparison with shortterm participants, such as a higher age and level of education, participation in associations and a lower incidence of off-farm employment. In addition to participation in the program, other variables found to be significant for farm income were land size, use of fertilizer and access to credit. These results suggest that although all participants in the program are small-scale and family farmers, there are differences in their technical and productive features that impact their profitability. Another interesting result is that those differences do not seem to be associated with either crop or animal production in particular. Our estimations also suggest that education and social capital are variables that provide more access to information and thus increase the probability of long-term participation of family farms in the program.

The results have several implications for public policy in Chile, especially for peri-urban family farmers and food security in urban areas. First, they show that integrated extension programs have a significant impact on the production value of farmers who participate in them long-term. This suggests that integrated programs are a strategy to consider in the context of agricultural development and that sustained participation is not necessarily due to an accommodative attitude. Second, facilitating access to land, credit and production techniques such as fertilization can lead to higher farm production value. Third, extension programs should take into account the significant differences among their beneficiaries that can determine impact. Finally, the results suggest the existence of selection bias regarding how long-term participants remain in the program. It is important to consider this to prevent public sector efforts from being co-opted by a specific farmer profile.

\section{Acknowledgment}

The authors acknowledge the assistance of the Government of Chile through the Ministry of Agriculture's Institute of Agricultural Development, INDAP, in carrying out the surveys conducted in this investigation. 


\title{
Resumen
}

\begin{abstract}
S. Boza y R. Jara-Rojas. 2018. Agricultura familiar peri urbana y resultados económicos: El efecto de la participación a largo plazo en un programa de extensión en un área metropolitana. Cien. Inv. Agr. 45(3): 200-209. El objetivo de este artículo es evaluar el efecto de la participación en el largo plazo en un programa de extensión en los resultados económicos de agricultores familiares peri-urbanos. Para ello, se aplicó una encuesta a una muestra de 156 beneficiarios del Programa de Desarrollo Local (PRODESAL) del Instituto de Desarrollo Agropecuario (INDAP) en la Región Metropolitana de Santiago. La mitad de los agricultores encuestados son participantes de largo plazo en el programa con al menos cuatro años y la otra mitad eran beneficiarios hacía un año. Se utilizó un modelo de regresión con una variable binaria endógena para identificar las diferencias entre participantes de largo y corto plazo en PRODESAL. La primera etapa del modelo es una regresión Probit que identifica los factores que influencian la participación de largo plazo en PRODESAL. La segunda etapa tiene como variable dependiente el valor total de la producción (VTP), la cual captura los resultados económicos. Una de las variables explicativas es el regresor binario endógeno de la primera etapa del modelo. Los resultados muestran un impacto positivo de la participación de largo plazo en PRODESAL en el VTP. Otras variables, como el tamaño predial, la fertilización y el acceso a créditos, también fueron significativas y positivas. La educación y el capital social se evidencian como variables que incrementan la probabilidad de participación de largo plazo en el programa.
\end{abstract}

Palabras clave: agricultura peri-urbana, Chile, participación de largo plazo, programa integral de extensión, Región Metropolitana.

\section{References}

Aedo, M., and J.J. Alvear. 2010. Micro y Pequeña Empresa Agropecuaria en Chile: Criterios para una Focalización Eficiente de las Políticas para el Sector de acuerdo al VII Censo Agropecuario. Santiago, Chile: INDAP.

Aguirre, F. 2012. El nuevo impulso de la extensión rural en América Latina. Situación actual y perspectivas. Red Latinoamericana para los Servicios de Extensión Rural, Santiago, Chile.

Banco Central. 2016. Cuentas nacionales de Chile: PIB regional 2015. Banco Central, Santiago, Chile.

Berdegué, J.A., and C. Marchant. 2002. Chile: The Evolution of the Agricultural Advisory. In: Rivera, W.M., and W. Zijp (Eds.). Contracting for Agricultural Extension: International Case Studies and Emerging Practices. CABI Publishing, New York.

Berdegué, J.A., and F. Rojas. 2014. La agricultura familiar en Chile. Documento de trabajo, Grupo de Tra- bajo Desarrollo con Cohesión Territorial, No. 152.

Boza, S., M. Cortés, T. Muñoz, M. Rico, and J. Muñoz. 2018. Development programs for female farmers: identifying clusters for the case of Chile's "Education and training program for rural women". Revista de la Facultad de Ciencias Agrarias 50(1):141-155.

Boza, S., G. Marcos, M. Cortés, and M. Mora. 2016a. Profiles based on attitudes toward public support programs of rural micro entrepreneurs of central Chile. Revista de la Facultad de Ciencias Agrarias 48(2):161-175.

Boza, S., M. Cortés, and T. Muñoz. 2016b. Estrategias de desarrollo rural con enfoque de género en Chile: el caso del programa Formación y Capacitación para Mujeres Campesinas. Revista Civilizar 16:63-75.

Brooks, J. 2010. Agricultural Policy Choices in Developing Countries: A Synthesis. Paper presented at the Global Forum on Agriculture, OECD. Paris, 29 - 30 November. 
Cáceres, C. 2015. Expansión residencial en comunas periurbanas de Santiago de Chile: organización territorial y nuevas lógicas de generación de centralidades urbanas en el Santiago periurbano. Revista Diseño Urbano y Paisaje. 30:18-24.

Cameron, C., and P.K. Trivedi. 2010. Microeconometrics using STATA. College Station, TX, US: STATA Press

Challies, E., and W.E. Murray 2011. The Interaction of Global Value Chains and Rural Livelihoods: The Case of Smallholder Raspberry Growers in Chile. Journal of Agrarian Change 11:29-59.

Dethier, J.J., and A. Effenberg. 2012. Agriculture and Development: A Brief Review of the Literature. Economic Systems. 36(2):175-205.

Donoso, G., O. Melo, and E. Negrete. 2010. Participation determinants and impact assessment of the Institute of Agricultural Development (INDAP) credit program. Ciencia e Investigación Agraria. 37(2):87-99.

Duflo, E., M. Kremer, and J. Robinson. 2008. How High Are Rates of Return to Fertilizer? Evidence from Field Experiments in Kenya. American Economic Review: Papers \& Proceedings. 98(2):482-488.

FAO. 2014. Ciudades más verdes en América Latina y el Caribe. Un informe de la FAO sobre la agricultura urbana y peri urbana en la región. Rome, Italy. FAO.

Girabi, F., and A.E. Godfrey. 2013. Impact of Microfinance on Smallholder Farm Productivity in Tanzania: The Case of Iramba District. Asian Economic and Financial Review. 3(2):227-242.

Graeub, B., M.J. Chapell, H. Wittman, S. Ledermann, R. Bezner, and B. Gemmill-Herren. 2016. The State of Family Farms in the World. World Development. 87:1-15.

Handschuch, C., M. Wollni, and P. Villalobos. 2013. Adoption of food safety and quality standards among Chilean raspberry producers - Do smallholders benefit? Food Policy 40:64-73.

IDB. 2015. The experience of Latin America and the Caribbean in Urbanization. Washington DC, US: Inter-American Development Bank.

INDAP. 2017. Modifica las normas técnicas y pro- cedimientos operativos del Programa de Desarrollo Local (PRODESAL) aprobadas por Resolución Exenta $n^{\circ} 98584$ de 07/07/2015 y sus modificaciones, y aprueba texto refundido. Disponible en: https://www.indap.gob.cl/ docs/default-source/default-document-library/ normas-técnicas-y-procedimientos-operativosprodesal-(al-22-8-2017).pdf?sfvrsn=0.

INDAP. 2018. INDAP en cifras 2017. Disponible en: https://www.indap.gob.cl/biblioteca/documentos-indap/!k/indap-en-cifras-(primer-semestre-2017)

INE. 2007. Cambios Estructurales en la Agricultura Chilena: Análisis Intercensal 1976-1997-2007. Instituto Nacional de Estadísticas, Santiago, Chile.

Jacoby, E., C. Tirado, A. Díaz, M. Peña, A. Sanches (...) and C. Courtis. 2014. A Comprehensive Look at Public Policies on Family Farming, Food Security, Nutrition, and Public Health in the Americas: Linking United Nations Work Agendas. PAHO, FAO, ECLAC, IICA and Office of the United Nations High Commissioner for Human Rights.

Jara-Rojas, R., J. Díaz, P. Manríquez, and A. Rojas. 2012. Classification criteria and commercial profile re-definition of the Family Farm Agriculture in Chile, Maule region. Revista de la Facultad de Ciencias Agrarias 44(1):143-156.

Jara-Rojas, R., B. Bravo-Ureta, D. Solís, and D. Martínez. 2018. Technical efficiency and marketing channels among small scale farmers: evidence for raspberry production in Chile. International Food and Agribusiness Management Review 21(3):351-364.

Jonasson, E., M. Filipski, J. Brooks, and J.E. Taylor. 2014. Modeling the Welfare Impacts of Agricultural Policies in Developing Countries. Journal of Policy Modeling. 36(1):63-82.

Khandker, S.R., and G.B. Koolwal. 2016. How Has Microcredit Supported Agriculture? Evidence Using Panel Data from Bangladesh. Agricultural Economics. 47(2):157-168.

Lapola, D.M., L.A. Martinelli, C.A. Peres, J.P.H.B. Ometto, M.E. Ferreira, (...), and I.C.G. Vieira. 2014. Pervasive transition of the Brazilian landuse system. Nature Climate Change. 4:27-35. 
Li, S. 2018. Change detection: how has urban expansion in Buenos Aires metropolitan region affected croplands. International Journal of Digital Earth. 11(2):195-211.

Mavimbela, P., M.B. Masuku, and A. Belete. 2010. Contribution of Savings and Credit Cooperatives to Food Crop Production in Swaziland: A Case Study of Smallholder Farmers. African Journal of Agricultural Research 5(21):2868-2874.

Medina, G., C. Almeida, E. Novaes, J. Godar, and B. Pokomy. 2015. Development Conditions for Family Farming: Lessons from Brazil. World Development. 74:386-396.

Namdar-Irani, M., and O. Sotomayor. 2011. Le conseil agricole au Chili face à la diversité des agriculteurs. Cahiers Agricultures. 20(5):352-358.

ODEPA. 2018. Región Metropolitana. Información regional 2018. Oficina de Estudios y Políticas Agrarias, Santiago, Chile. Disponible en: https:// www.odepa.gob.cl/wp-content/uploads/2018/03/ Metropolitana.pdf

PUC. 2010. Evaluación de impacto. Informe final: Programa De Desarrollo Local (PRODESAL) y Programa De Desarrollo De Comunas Pobres (PRODECOP). Pontificia Universidad Católica de Chile, Santiago, Chile.

Ramírez, E., A. Furnano, J. Berdegué, G. Escobar, and L. Romero. 2014. Evaluación de programas de INDAP. Informe editado en su version final. Agraria, Santiago, Chile.
Reyes, A., and R. Lensink. 2011. The Credit Constraints of Market-Oriented Farmers in Chile. Journal of Development Studies. 47(12):18511868. DOI: $10.1080 / 00220388.2011 .57911$

Sabourin, E., M. Samper, and O. Sotomayor. 2014. Políticas públicas y agriculturas familiares en América Latina y el Caribe Balance, desafíos y perspectivas. Santiago, Chile: Naciones Unidas.

Saleem, M.A., and F.A. Jan. 2011. The Impact of Agricultural Credit on Agricultural Productivity in Dera Ismail Khan (District). European Journal of Business and Management. 42(4):469-485.

Sheahan, M., R. Black, and T.S. Jayne. 2013. Are Kenyan Farmers Under-utilizing Fertilizer? Implications for Input Intensification Strategies and Research. Food Policy. 41:39-52.

Van Vliet, J., A. Schut, P. Reidsma, K. Descheemaeker, M. Slingerland, G. Van de Ven, and K. Giller. 2015. De-mystifying Family Farming: Features, Diversity and Trends across the Globe. Global Food Security. 5:11-18.

von Cramon-Taubadel, S., and R. Saldías. 2014. Access to Credit and Determinants of Technical Inefficiency of Specialized Smallholder Farmers in Chile. Chilean Journal of Agricultural Research. 74(4):413-420.

Zeeuw, H. and M. Dubbeling. 2009. Cities, Food and Agriculture: Challenges and the way forward. RUAF Working Paper, No. 3. 